NBER WORKING PAPER SERIES

THE ROLE OF GLOBALIZATION IN THE WITHIN-INDUSTRY SHIFT AWAY FROM UNSKILLED WORKERS IN FRANCE

\author{
Vanessa Strauss-Kahn \\ Working Paper 9716 \\ http://www.nber.org/papers/w9716 \\ NATIONAL BUREAU OF ECONOMIC RESEARCH
1050 Massachusetts Avenue
Cambridge, MA 02138
}

May 2003

I would like to thank Raquel Fernandez, Kei-Mu Yi, Christopher Flinn, the editors Robert Baldwin and L. Alan Winters and participants at the ISIT conference for helpful comments on previous version of this paper. I am also grateful to Bernard Salanié and Sébastien Jean for their help in collecting the data used in this paper. The usual disclaimer applies. The views expressed herein are those of the authors and not necessarily those of the National Bureau of Economic Research.

C2003 by Vanessa Strauss-Kahn. All rights reserved. Short sections of text not to exceed two paragraphs, may be quoted without explicit permission provided that full credit including $(\mathcal{C}$ notice, is given to the source. 
The Role of Globalization in the Within-Industry Shift Away from Unskilled Workers in France Vanessa Strauss-Kahn NBER Working Paper No. 9716

May 2003

JEL No. F15, F16

\begin{abstract}
Growth in international trade and globalization has been correlated in nearly all countries with a worsening of the less skilled labor situation relative to the skilled. In this empirical paper, I show that an important component of recent globalization in France has been a huge growth in vertical specialization - the completion of the different production stages of a good in different countries. By shifting relative labor demand across countries, globalization of this form could explain the poor relative showing of unskilled labor in industrial countries. Using input-output tables and labor data, I find that in France vertical specialization - defined as the share of imported inputs in production - rose from $9 \%$ in 1977 to $14 \%$ in 1993. Further estimations show that vertical specialization contributed from $11 \%$ to $15 \%$ of the decline in the share of unskilled workers in French manufacturing employment for the 1977-1985 period and for 25\% of the decline in the 1985-1993 period.
\end{abstract}

Vanessa Strauss-Kahn

Assistant professor of Economics

INSEAD

Bd de Constance

77305 Fontainebleau, France

vanessa.strauss-kahn@insead.edu 


\section{The Role of Globalization in the Within-Industry Shift Away from Unskilled Workers in France}

\section{Introduction}

An important correlate of recent extensions in international trade and globalization has been the observation that in nearly all countries less skilled labor has fared less well than skilled labor. In some cases the wages of the unskilled have fallen absolutely whereas elsewhere they have just increased much less rapidly. Likewise, while job opportunities for the skilled have been increasing strongly, those for the unskilled have been falling, frequently resulting in high involuntary unemployment rates among them. At the same time, an important component of recent globalization has been the huge growth in vertical specialization - the completion of the different production stages of a good in different countries and the international transportation of parts and components between countries. Moreover, the trends suggest that such 'dividing up of the value chain' is likely to become more important in future.

This paper asks whether these two phenomena are linked - in particular whether vertical fragmentation has allowed firms to move unskilled-labor-intensive activities away from industrial countries and towards less-developed ones, and thus to reduce their demand for the relatively expensive unskilled workers in the former. If so, globalization of this form could explain the poor relative showing of unskilled labor in industrial countries. This in turn suggests that the internal politics of trade liberalization and international investment will become more difficult and complex, as the unskilled - already a major force in industrial country trade policy determination - become further detached from the increase in prosperity. Ultimately, such distributional consequences of globalization will need to be addressed by governments, by means of complementary policies or even by modifying the nature or extent of openness.

Strauss-Kahn (2002) sets forth theoretically the potential role of trade (via international vertical specialization) in explaining an increase in the within-industry share of unskilled labor. This paper aims at assessing empirically the magnitude of this vertical specialization effect. I first 
show that international vertical specialization occurred in France over the past two decades and then estimate its contribution to the observed within-industry shift away from unskilled workers. Following Krugman's (1995) argument, I focus on employment rather than wages because of the particularly inflexible aspects of the French labor market (e.g., strong unions and a high minimum wage). This choice will be discussed more extensively in Section 4. To determine the extent of international vertical specialization, I build an index that measures the value of imported inputs embodied in goods produced, using primarily data from input-output tables. The labor data used in the regression analysis distinguish workers per occupation within industry. All data come from the French National Institute of Statistics and Economic Studies (INSEE). ${ }^{2}$ I find that international vertical specialization rose significantly over the period, from $9 \%$ in 1977 to $14 \%$ in 1993. A more limited index, restricted to inputs purchased from the same aggregated sector as the good being produced, shows an increase from $5 \%$ to $7.5 \%$ for the same period. I then show that international vertical specialization has contributed from $11 \%$ to $15 \%$ of the decline in the share of unskilled workers in manufacturing employment over the 1977-1985 period and for 25\% of the decline in the 1985-1993 period.

France has several relevant characteristics that make it a particularly good case study. It has a large and diverse trading area because of (among other factors) preferential trade agreements with Eastern European countries and former colonies. Moreover, the scope of free markets in France has dramatically increased over the past three decades, as the European Union (EU) has been enlarged from six to fifteen member states and the free movement of goods, persons, services, and capital among members has been progressively established. Because labor costs differ across member countries, this market integration has probably increased international vertical specialization between France and its partners. In addition, the high French unemployment rate affects unskilled workers more than their skilled counterparts. The skilled-unskilled unemployment rate differential in France widened in the 1980s, rising from 2.4 percentage points

\footnotetext{
${ }^{2}$ Sebastien Jean has kindly provided the labor data used in this paper. The industry occupational decomposition is derived from an annual industry survey managed by the INSEE. The distinction between skilled and unskilled workers depends on occupation rather than education. Occupations have been divided into two groups that are roughly equivalent to the U.S. white-collar /blue-collar decomposition. For further information on these data, see Cortes and Jean (1997).
} 
in 1981 to 7.6 percentage points in $1994 .^{3}$ This increase in the unemployment rate of unskilled workers has been accompanied by a decrease in the share of the unskilled in total employment, as labor demand has shifted away from unskilled workers. Accordingly, many French citizens perceive international vertical specialization as one of the main causes of unskilled unemployment. To my knowledge, the accuracy of this belief has yet to be tested in any empirical work.

This paper is related to two strands of literature: one on vertical specialization and the other on the impact of trade on income distribution. Campa and Goldberg (1997) study vertical specialization in Japan, the United Kingdom, Canada, and the United States; Hummels et al. (1999) consider the French case among other countries in the OECD (Organization for Economic Cooperation and Development). While both papers focus on the magnitude and evolution of vertical specialization, they neglect the effect of vertical specialization on the labor market. I also use a different index of vertical specialization and a higher level of industrial disaggregation than Hummels et al. In the large literature on trade and income distribution, my work is closest to Feenstra and Hanson (1996, 1997), who estimate the impact of outsourcing (vertical specialization) for the United States. They find that outsourcing made a significant contribution in explaining the observed increase in the relative wages of skilled workers during the 1980s.

The remainder of the paper is in five parts. Section 2 explains my measure of vertical specialization and the data used to construct it. It also presents results on vertical specialization levels and trends. In Section 3, I examine the accuracy of the index by carrying out two different variance decompositions. Section 4 presents evidence on the within industries shift away from unskilled labor. In Section 5, I estimate the impact of vertical specialization on employment inequality through a regression analysis. Section 6 concludes.

\section{The index of vertical specialization}

\footnotetext{
${ }^{3}$ The unemployment rate for males with low education (i.e., levels $0,1,2$ up to lower secondary education) rose from $5.4 \%$ in 1981 to $13.5 \%$ in 1994 . The unemployment rate for males with high education (levels up to tertiary education) increased from $3.0 \%$ in 1981 to $5.9 \%$ in 1994 . The gap for female unemployment rate by education level is even larger. Data are from the OECD.
} 
In order to assess the degree of vertical specialization across industries and its evolution over time, I build and study an index denoted by $V$. The index is computed at the industry level and measures the share of imported inputs embodied in production. I primarily use input-output tables that include sector-level data on inputs. Data for outputs, value added, imports, and consumption are derived from national account tables. All data come from INSEE and encompass 100 sectors, among which 50 are of interest for this paper. ${ }^{4}$ The database covers the $1977-1993$ period. Inputoutput tables provide the value of inputs used in production and distinguish between the different sources of supplies (i.e., the industries in which the inputs have been produced). However, these tables do not distinguish between domestically-produced and imported inputs. In order to obtain an estimate of the value of imported input from industry $j$ used in producing the output of industry $i$, I multiply the total value of inputs from industry $j$ used in producing the output of industry $i$, namely, $q_{j i}$, by the ratio of the value of imported goods from industry $j$ to the value of the domestic use of goods from industry $j$, namely, $m_{j}$, where domestic use includes use as final goods, intermediate goods, and capital goods. Dividing this estimate of imported inputs from industry $j$ by the value of total production in industry $i\left(p_{i}\right)$, and summing this ratio for all the $n$ industries with imported inputs into industry $i$ yields the vertical specialization index for industry $i$, namely, $V_{i}$. In equation terms,

$$
V_{i}=\sum_{j=1}^{n} \frac{m_{j} q_{j i}}{p_{i}} .
$$

The fact that the import penetration ratio mixes final goods, intermediate goods, and capital goods limits the precision of the index. It is indeed likely that the share of imported inputs in total consumption of intermediate inputs differs from the share of imported final goods in total consumption of final goods. One might expect the first ratio to be lower than the second due to quality/adequacy issues of international trade in intermediate goods. If such is the case, the index

\footnotetext{
${ }^{4}$ The 100 sectors are divided in six industries: agriculture, business, manufacture, mining, services, and transportation. Agriculture, mining and manufacture account for $90 \%$ of traded goods and are the sectors covered in this study. $\mathrm{V}$ has been computed for the services, transportation, and business sectors, however, and indicates low levels of vertical specialization (under $5 \%$ in 1996).
} 
of international vertical specialization is overstated. However, because changes in variables are considered in the regression analysis, this issue is not a significant concern. More importantly, it is likely that imports in intermediate goods do not vary across industries in the same proportion as imports in final goods over the period considered. The manner in which this issue will bias the index is however unclear. Given this limitation, the import penetration ratio is used as the best available approximation of the share of intermediate-goods imports in intermediate-goods consumption.

This index $V$ seems to capture adequately any changes in production structure toward more or less international vertical specialization (i.e., if $V$ increases then an industry becomes more vertically specialized). However, in order to measure the impact of vertical specialization on unskilled labor shares, I also calculate a modified version of the original index. The modified index only measures inputs purchased from the same aggregated sector as the good being produced. This provides information on the relative extent of international intermediate-goods specialization within the same industry. As most of the decline in unskilled labor shares occurred within industries (see section 4), the modified index captures such an intra-industry movement. The rationale of using the so-called limited index may be illustrated as follows. If (to use a common example) the French automobile industry imports more steel, this will not affect French workers in the automobile industry but rather those in the steel industry. In contrast, if the French automobile industry imports more automobile parts then automobile workers will be affected especially if the parts were formerly made by the same company (or, at least, were purchased in France). The limited index of vertical specialization, $V l$, is constructed the same way as $V$, with the input subscripts $i$ and $j$ belonging to the same aggregated sectors (i.e., three-digit industry $j$ belongs to two-digit industry $i$.)

In constructing the $V l$ index, I would ideally like to have firm-specific data on the production process that included the amount of imported inputs in total production, among which are parts and components and also contracts done by others. Such data would be more precise than the data used here and would provide information on stages of production that are located abroad. For example, many French-contracted goods involve domestic design, marketing, and headquarter activities but are produced abroad and then directly exported to their final destination. Hence 
such goods do not appear in the French input-output tables. This type of outsourcing, which tends to separate production and non-production activities internationally, has dramatically increased over the past few decades. Among the multitude of European and United States branded goods made abroad, a typical example is Nike, ${ }^{5}$ which employs 2,500 persons for marketing and headquarter activities in the United States and about 75,000 persons for production activities in Asia. Firm-specific data are collected for the United States in the Annual Survey of Manufactures. ${ }^{6}$ Unfortunately, equivalent data does not exist for France. The unavailability of "contracts done by others" data tends to reduce the level of international vertical specialization and therefore to underestimate its impact on the changes in the share of unskilled workers. Nevertheless, I believe that $V l$, using available data, captures a significant part of the vertical specialization trend. One should however keep in mind that $V l$ represents the lower bound of the potential magnitude of international vertical specialization.

Table 1 presents overall estimates of the level of international vertical specialization as measured by $V$ and $V l$, as well as sectoral results for selected industries. It also shows growth rates in the indices for the 1977-1993 period. Overall, $V$ increases from 9\% to 14\%, which represents more than a $50 \%$ growth over the period. Campa and Goldberg (1997) computed a similar measure of vertical specialization for the 1974-1993 period for the United-States and other countries. They found that $V$ rose from $4 \%$ to $8 \%$ in the United States, from $16 \%$ to $20 \%$ in Canada, and from $13 \%$ to $22 \%$ in the United Kingdom. Japan, in contrast, experienced decreasing vertical specialization, with $V$ falling from $8 \%$ to $4 \%$. My growth rate estimates for France are roughly similar (although somewhat lower) to Campa and Goldberg's estimates for the United Kingdom when their longer coverage period is taken into account. This similarity may be explained by the fact that the two countries have several common features (European countries, part of the EU, size, etc). Moreover, Campa and Goldberg use more aggregated data (about 20 sectors) than in this paper and do not include the agricultural sector in their calculation, which tends to increase the index's value. ${ }^{7}$ Hummels et al. $(1998,1999)$ consider the value of imported inputs embodied in goods that are exported. Their measure, although more limited than mine, gives a useful

\footnotetext{
${ }^{5}$ Mentioned in Feenstra and Hanson (1996).

${ }^{6}$ The Annual Survey of Manufactures provides information, at a high level of disaggregation, on such outsourcing as (1) parts and components, (2) resales, and (3) contracts done by others.
} 
estimate of vertical specialization in goods sold abroad. However, my index measures the shift in labor demand whether the final good is exported or consumed domestically. Their index shows a rise in vertical specialization in France from $18 \%$ in 1972 to $24 \%$ in 1990 . Two factors inflate their index compared to mine. First, Hummels et al. take into account the imported inputs embodied in domestic inputs purchased. Second, sectors featuring the highest share of imported inputs are relatively more export-oriented (the correlation between the levels of vertical specialization and the level of export orientation is 0.45$).{ }^{8}$ This observation supports the idea of undertaking vertical specialization for cost-advantage reasons, since export-oriented sectors must be competitive in international markets.

- Insert Table 1 -

In examining $V$ by sector, two broad relationships emerge. ${ }^{9}$ First, the level of vertical specialization varies widely across sectors. Although certain industries experienced a rapid increase, $V$ declines in a number of industries, (e.g., iron mining or wood products). Second, the sectors most affected by international vertical specialization in France (in level as well as in trend) tend to be the same than in other countries. In France, among the industries that experience the greatest rise (for a significant level of $V$ ) are: chemicals and allied products (drugs and medicines, industrial chemicals, soaps and cosmetics and synthetic fibers), electronic computing equipment, non-electrical industrial machinery, textiles (apparel and other fabricated textile products, footwear industries, leather and leather products and textile industries), transportation equipment (aircraft, motor vehicles and ship and boat building) and rubber and plastics products. These findings are consistent with those of Hummels et al. and Campa and Goldberg for other industrial countries.

Results obtained with the restricted measure of international vertical specialization are also reported in Table 1. Overall, $V l$ increases from 5\% in 1977 to $7.5 \%$ in 1993, a 49\% growth over the period. As would be expected, $V l$ is lower than $V$ across all sectors. Certain sectors however

\footnotetext{
${ }^{7}$ Omitting the agricultural sector, the French vertical specialization rises from $10 \%$ in 1977 to $16 \%$ in 1993 , with a growth of $67 \%$.

${ }^{8}$ Author's calculation.

${ }^{9}$ Table 2 reports the index for selected representative sectors. Results for all sectors are available upon request.
} 
exhibit significantly high limited vertical specialization index and growth in limited vertical specialization. Such sectors belong to the chemicals and allied products industries, transportation equipment industries, machinery industries and textile industries. In these sectors it is apparently relatively easy to 'divide up the value chain' and import inputs from abroad.

Distinguishing international vertical specialization by regional source of imported inputs provides interesting results. In disaggregating these imports into OECD versus non-OECD import sources I find that the levels and growth rates of the overall $V$ and $V l$ can be mainly imputed to OECD imports. ${ }^{10}$ In fact, $79 \%$ of international vertical specialization is attributed to OECD countries in 1977, and $85 \%$ in 1993. Breaking the results down by subperiods reveals that vertical specialization involving OECD countries accounts for $100 \%$ of the growth in vertical specialization for $1977-1985$ but only $80 \%$ for 1985-1993. The importance of vertical specialization involving OECD countries reflects the French pattern of trade. ${ }^{11}$ However, results on trends are more significant. While import growth rates declined during the 1977-1993 period - from $64 \%$ for the $1977-1985$ period to $42 \%$ for the $1985-1993$ period - international vertical specialization growth rates increased over the period. Imports growth rates from OECD countries show a similar declining trend as total import growth rates. Growth rates in vertical specialization involving OECD countries reached $27 \%$ in the two subperiods. More importantly, whereas imports from non-OECD countries grew by 58\% from 1977 to 1985, vertical specialization involving non-member countries did not increase. However, for 1985-1993, imports from nonOECD countries grew by $54 \%$, with $V$ and $V l$ increasing by $16 \%$ and $21 \%$ respectively. This suggests that, in the second period, imports from non-OECD countries became more oriented toward sectors that vertically specialize. Sectoral decomposition of the international vertical specialization index shows a dramatic growth in $V$ and $V l$ from non-OECD countries in electronic computing equipment, office and computing machinery and all the textiles industries. It is plausible that some issues specific to trade in intermediate inputs, such as quality or adequacy of products along the production chain, became less important over time as communication (and thereby monitoring) was eased. Further research on patterns of trade and vertical specialization

\footnotetext{
${ }^{10}$ The OECD data used in this paper covers only those countries that were members prior to 1994 (i.e., the data exclude the Czech Republic, Hungary, Mexico, Poland, and South Korea).

${ }^{11}$ About 84\% of French imports came from OECD countries during 1977-1993, with this share being stable over the period.
} 
according to source countries would be of great interest. However, such research is beyond the scope of this paper, which focuses more specifically on the broad impact of international vertical specialization on French employment shares of unskilled and skilled workers. ${ }^{12}$

\section{Is the index a good measure of international vertical specialization?}

The index of international vertical specialization aims at capturing changes caused by the relocation of different stages of production across countries. International vertical specialization is hence expected to occur at the industry level and to increase international trade. Thus, it is important to verify (i) that the index captures the change in intensity of a sector's vertical specialization (and not the variation in sector composition of total production) and (ii) that it reflects variation in the share of imported inputs in production for a given level of inputs (and not variation in the use of inputs independently of the supply's source).

A rise in $V$ or $V l$ could be due simply to an increase in production shares of highly vertically specializing sectors relative to production of other sectors. I check for this possibility by decomposing the variance of $V$ and $V l$. The change in these indices for the 1977-1993 period is decomposed into the variation in intensity of sectors' vertical specialization (the within component) and the variation in sectors' shares of total production (the between component):

$$
\Delta V=\Delta \sum_{i=l}^{n} \theta_{i} V_{i}=\sum_{i=l}^{n} \bar{\theta}_{i} \Delta V_{i}+\sum_{i=l}^{n} \bar{V}_{i} \Delta \theta_{i}
$$

where $\theta_{i}$ is the industry $i$ 's share of total manufacturing production at time $t$. (Henceforth, a bar over a variable denotes the mean value over the considered period.)

Overall results of this variance decomposition are summarized in Table $2 .^{13}$ The between-andwithin sector decomposition of the rise in vertical specialization is indicated for the entire period

\footnotetext{
${ }^{12}$ Note that the importance of vertical specialization with OECD countries does not affect its potential impact on unskilled and skilled labor shares. Within the OECD, differences in labor costs could lead France to relocate its unskilled-intensive activities to lower-wage countries (e.g., southern European countries).

${ }^{13}$ Detailed results across sectors are available upon request.
} 
1977-1993 as well as for the subperiods $1977-1985$ and 1985-1993. The column labeled "Total" reports the annual percentage-point increase in vertical specialization. A comparison of the rates between periods shows an acceleration over time. In terms of $V(V l)$, the rise in vertical specialization occurred at a rate of $0.20(0.10)$ percentage points per year during the 1977-1985 period and increased to $0.31(0.17)$ percentage points per year during the $1985-1993$ period.

\section{- Insert Table 2 -}

The within component dominates in both periods, accounting for $0.20(0.09)$ of the $0.20(0.10)$ percentage-point per-annum increase in vertical specialization for $V(V l)$ in the 1977-1985 period and for all the acceleration between the two periods. Over all sectors, the within component of the variance decomposition accounts for almost 98\% (101\%) of the total variation in vertical specialization indices for 1977-1993. The increase in $V$ and $V l$ is thus due mainly to an increase in individual sector's vertical specialization intensity.

I also want to determine if the observed vertical specialization is internationally oriented. The growth in $V$ and $V l$ could actually be caused either by an increase in the use of inputs from all sources or by a shift from domestically-produced inputs to imported inputs. Obviously, vertical specialization affects the domestic labor market only if it occurs internationally, substituting foreign for French labor. For this purpose, I decompose the variance of the index of vertical specialization by industry into the variation in the use of production inputs, independently of the supply's sources (the within component) and the variation in share of imported input in production for a given level of inputs (the between component):

$$
\Delta V_{i}=\sum_{j=1}^{n} \bar{m}_{j} \Delta\left(\frac{q_{j i}}{p_{i}}\right)+\sum_{j=l}^{n}\left(\frac{q_{j i}}{p_{i}}\right) \Delta m_{j},
$$

where $V_{i}$ is the level of vertical specialization in sector $i, m_{j}$ is the import penetration ratio of industry $j, q_{j i}$ is the value of inputs from industry $j$ used in the production of industry $i, p_{i}$ is the value of total production in industry $i$, and $n$ is the number of industries considered. 
Overall results of this decomposition are presented in Table 3. ${ }^{14}$ The between component, which corresponds to a rise in foreign outsourcing, accounts for all the increase in vertical specialization in each period and thus, for all the acceleration. As measured by $V(V l)$, it increases from 0.23 (0.11) percentage points per year during the $1977-1985$ period to $0.31(0.19)$ percentage points per year during the 1985-1993 period. The within component, which captures the annual rate of change in outsourcing from all sources, is negative and stable over the entire period.

The variance decompositions indicate that vertical specialization occurs within-industry and internationally. While results from the second decomposition are in accordance with the findings of Thesmar and Thoenig (2002), the fact that we do not observe any decrease in the use of inputs from all sources (the within component) is somewhat surprising. However, sectoral results show that this feature varies widely across industries. In most machinery, textile, and transportation industries, the within component accounts for a significant share of vertical specialization (i.e., these industries outsource more of their inputs independently of the supply source.) For example, the within component represents $20 \%$ of total change in the footwear industry and $30 \%$ in the motor vehicles industry. In contrast, most agriculture and mining industries show a negative within component, suggesting that these industries have become increasingly self-sufficient over time. Technological progress could explain part of this latter development, as new machines and techniques may allow firms to produce goods that would have been outsourced otherwise. Excluding the agriculture and mining sectors changes the overall decomposition results. The between component now accounts for only $93 \%$ of the total change. In any case, these results suggest that most of the vertical specialization occurs internationally as imports substitute for inputs outsourced from other domestic firms.

\section{The within-industry shift away from unskilled workers}

\footnotetext{
${ }^{14}$ Sector results are available upon request.
} 
In order to analyze the declining intra-industry share of skilled to unskilled workers or the widening wage gap between skilled and unskilled workers, one must consider both supply and demand factors. However, there is evidence that changes in the relative supply of skilled to unskilled labor did not play a major role. In most industrialized countries, the share of skilled workers in the labor force rose over the period being studied. For example, the ratio of low-to high-educated workers in the French population decreased from 6.6 in 1981 to 2.7 in 1994; for the United Kingdom, the decline is from 3.6 in 1984 to 1.3 in $1994 .{ }^{15}$ One would expect this change in relative supply to be reflected by a decline in the relative wage of skilled workers and an increase in the ratio of skilled to unskilled workers across industries. Hence, the observed increase in wage premia for skilled workers seems to refute the hypothesis of predominant supply-side effects on wage inequality. Moreover, although the supply of unskilled workers fell relative to the supply of skilled workers, evidence on the employment/population ratio for these two groups indicates a relative decline for unskilled workers. For example, in France the difference in the employment/population ratio for high-versus less skilled workers increased by more than 11 percentage points over the 1981-1994 period. ${ }^{16}$ Therefore, in analyzing these changes, I focus on the demand side of the labor market.

In this paper, I focus on the employment shares of skilled versus unskilled workers. Although it could be argued that one should focus on the change in the relative wages (earnings) of these two groups, I believe that changes in employment shares is the more appropriate variable to analyze in considering the French case. Over the past three decades, the French earnings dispersion between skilled and unskilled workers did not significantly rise whereas France's employment share of skilled workers increased dramatically. This behavior of relative wages is common to most Continental Europe countries and differs greatly from the United Kingdom and United States experience. Data from the OECD Employment Outlook $(1996,1997)$ show the trends: earnings dispersion (as measured by the ratio of the upper earnings limit of the ninth decile of workers to the first decile) shows a significant increase in the United States and the United Kingdom over the 1970-1995 period, while it is stable for France and for most Continental

\footnotetext{
${ }^{15}$ A low level of education corresponds to levels up to lower secondary education. A high level of education corresponds to levels up to tertiary education.

${ }^{16}$ All data in this paragraph are from the OECD Employment Outlook (1997).
} 
European countries. ${ }^{17}$ Moreover, employment-share differentials between more-educated and less-educated workers rose by 95\% for the 1981-1994 period in France yet increased by only $28 \%$ in the United States and $48 \%$ in the United Kingdom for equivalent periods. This suggests significant factor-price rigidities in the French labor market and the strong role of institutions and regulations. In fact, strong unions and a high minimum wage have probably compressed wage dispersion in Continental Europe and have induced instead an increasing employment-share differential. Hence, following Krugman (1995), I believe that in Europe the effects of trade are manifested mainly in changes in industry employment shares of less-educated (unskilled) versus more-educated (skilled) workers.

If firms vertically specialize to take advantage of labor-cost differentials across countries, the skilled-unskilled relative demand for labor should change within industries. In relatively high skill countries (such as France), the share of unskilled workers within industries should decrease as firms outsource their unskilled-intensive stages of production. In fact, vertical specialization, as well as skilled-biased technological change, shifts the skill composition of labor demand within industries. In contrast, trade in final goods shifts the skill composition of labor demand between industries: from unskilled-intensive to skilled-intensive industries. A variance decomposition analysis of the aggregate shift away from unskilled labor indicates which of these effects has been dominant in France during the past two decades. Following Berman et al. (1994), the change in the aggregate share of unskilled workers in total employment is decomposed into the change in the allocation of employment across industries (the between component) and the change in the allocation of employment within industries (the within component):

$$
\Delta E=\sum_{i=j}^{n} \bar{E}_{i} \Delta s_{i}+\sum_{i=l}^{n} \bar{s}_{i} \Delta E_{i}
$$

where $s_{i}$ is the employment share of industry $i$ at the national level. The $E$ term denotes the aggregate share of unskilled workers, i.e., $E=\sum_{i=l}^{n} E_{i} s_{i}$ where $E_{i}$ is the share of unskilled workers in industry $i$.

\footnotetext{
${ }^{17}$ This feature is robust to the choice of deciles.
} 
Tables $4 \mathrm{~A}$ and $4 \mathrm{~B}$ report the within-and-between components of the change in the aggregate share of unskilled workers for the entire economy and for the manufacturing sector. Over all sectors, the shift away from unskilled labor occurs at a rate of 0.65 percentage points per year for 1977-1985 and accelerates to 0.69 percentage points per year for 1985-1993. The annual rate of decrease is lower when only the manufacturing sector is considered ( 0.53 percentage points per year over the entire period) and shows a deceleration between the two periods.

- Insert Tables 4A and 4B -

The within component strongly dominates in each period. In the manufacturing sector, for example, it accounts for 0.46 percentage points of the 0.53 percentage points per annum decrease. The within-industry shift away from unskilled workers accounts for $86 \%$ of the fall in demand for this type of worker in total manufacturing employment.

To explain the change in the employment shares of unskilled and skilled workers, one must therefore focus on factors that affect the within-industry employment structure. As mentioned earlier, vertical specialization and skilled-biased technological progress are the most likely explanatory factors.

\section{Estimation of the impact of vertical specialization on the labor market}

The contribution of vertical specialization to the observed decrease in the within-industry share of unskilled workers is assessed through a regression analysis. ${ }^{18}$ An appropriate way to do so is to estimate a cost function. Following Berman et al. (1994) and Feenstra and Hanson (1996, 1997), I estimate a cost-share equation of a translog function. This specification allows using the withinindustry share of unskilled workers as dependent variable in a regression that estimates the parameters of the cost function. Related studies in the literature use instead the change in the share of less-skilled workers in industry wage bill. While it is theoretically a more appropriate 
regressand, as it results directly from the short-run cost-minimization problem of firms which face a translog production technology, I believe that using change in the share of less-skilled workers in industry employment is appropriate for France. As already discussed in the previous section, relative wages of unskilled to skilled workers in Continental Europe countries such as France have been relatively stable over the period and thus the main impact of vertical specialization has been on changing the employment share of unskilled workers within industries. Brown and Christensen (1981) also show that, with such a specification, level data can be used for quasi-fixed factors. This allows me to use quantity data for the quasi-fixed factor (i.e., capital) instead of price data, which are rarely available. Thus, the specification for estimating the change in the share of unskilled labor in industry $i$ over the time period $t$, namely, $\delta E_{i t}$, is:

$$
\delta E_{i t}=\beta_{0}+\beta_{1} \delta \ln \left(\frac{W_{u i t}}{W_{s i t}}\right)+\beta_{2} \delta \ln \left(\frac{K_{i t}}{Y_{i t}}\right)+\beta_{3} \delta \ln Y_{i t}+\beta_{4} \delta V_{i t}+\beta_{5} P D_{t}+\varepsilon_{i t}
$$

Here, for each period $t, E_{i}$ is the share of unskilled workers in industry $i, W_{u i} / W_{s i}$ represents the relative wages of skilled to unskilled labor in industry $i, K_{i}$ is industry $i$ 's level of capital utilization, $Y_{i}$ is industry $i$ 's level of gross output, $V_{i}$ is industry $i$ 's level of vertical specialization, and $P D$ is a period dummy.

The sign of the coefficient on the (logarithmic) relative wage, $\beta_{l}$, is ambiguous and depends on the elasticity of substitution between skilled and unskilled labor. The coefficient on the (logarithmic) share of capital in production, $\beta_{2}$, should be negative owing to the substitutability between capital and unskilled labor. Similarly, the coefficient on the (logarithmic) level of output, $\beta_{3}$, is expected to be negative. The output regressor controls for industry scale, and I expect firms to take the opportunity of increased production to decrease their share of unskilled labor. Such an outcome is likely in a rigid labor market such as the French one, where layoffs are cumbersome and costly. The coefficient on the (logarithmic) index of international vertical specialization, $\beta_{4}$, should have a negative sign because French and foreign unskilled labor are supposedly substitutes, and vertical specialization should take place to exploit lower unskilled

\footnotetext{
${ }^{18}$ In the rest of the paper, the limited measure of international vertical specialization is used in all the calculations, although it will be referred to as vertical specialization.
} 
labor cost abroad. The measure $\beta_{0}$, of cross-industry changes (including technological progress and institutional change) is expected to be negative. Finally, $\beta_{0}+\varepsilon_{i}$ represents industry-specific changes.

Following Berman et al. (1994) I assume that, although there might be some industry-specific mixes of skill types, the relative price of labor does not vary across industries. Then, to avoid endogeneity problems, I omit relative wages from regression (5.1). This omission should affect only the constant term. Thus, the estimated regression is

$$
\delta E_{i t}=\beta_{0}+\beta_{1} \delta \ln \left(\frac{K_{i t}}{Y_{i t}}\right)+\beta_{2} \delta \ln Y_{i t}+\beta_{4} P D_{t}+\epsilon_{i t} .
$$

Endogeneity problems may arise when estimating (5.2), since changes in the dependent variable and changes in capital utilization may be correlated. There are, indeed, factors (such as computer innovations), that could simultaneously affect the share of unskilled workers in total employment and the level of capital. Consequently, the independent variable $K_{i t}$ and the unexplained change in the share of unskilled labor (captured in $\varepsilon_{i}$ ) could be correlated. This is a serious issue because the correlation might significantly bias the slope estimates. Two different approaches are considered to address this problem.

For the capital variable, I use both net capital stock and electricity consumption as proxies. Net capital stock data, provided by INSEE, are constructed according to the rule of perpetual inventories. This method provides estimated data on net capital stock which are measured with error. More importantly, French data on net capital stock are not available at a high level of industrial disaggregation - a restriction that limits the estimation possibilities. ${ }^{19}$ I therefore use electricity consumption as a proxy for capital at the three-digit industry level. This strategy was first used by Griliches and Jorgenson (1967) and thereafter by (among others) Costello (1993) and Burnside, et al. (1995). All these authors argue that electricity consumption is a good measure of capital utilization, and Anxo and Sterner (1994) offer convincing proof in a paper 
devoted to the issue. Regression analysis performed with both measures of capital at the two-digit industry level confirms that the choice of the proxy used for capital does not significantly affect the results.

Assessing endogeneity therefore implies considering both capital stock and electricity consumption as measures of capital. Following Berman et al. (1994) I assume that, when net capital stock is used, the endogeneity bias should not be significant because investments in capital and change in the share of unskilled workers should not have the same timing, since new investments last several years. I also instrument electricity consumption by its lagged values to verify that it is not an endogenous variable. Past electricity consumption is, a priori, a good instrument since it is not affected by current innovation and since it is correlated (at more than $30 \%$ ) with current electricity consumption. Estimations (not reported here but available upon request) show that the effect of changes in electricity consumption on changes in the unskilled share in employment is robust with respect to the instrumentation. A Hausman test confirms that electricity consumption is nonendogenous.

Determining the appropriate data to be used for $Y$ is also a concern. Two potential candidates are value added and gross output. Berman et al. (1994) use value added, since labor and capital are the only independent variables in their specification. Feenstra and Hanson $(1996,1997)$ include a measure of outsourcing as regressor but also equate $Y$ to value added. ${ }^{20}$ Specification (5.2) introduces data on material inputs other than capital and labor (recall that vertical specialization is the share of imported inputs in production). Hence gross output would seem to be a more appropriate measure for $Y$. However, results are robust to the use of value added. ${ }^{21}$

It is necessary to control for the output level in regression (5.2). Wald tests performed on regression (5.2) strongly confirm that omitting $Y$ would misspecify the model, as the null

\footnotetext{
${ }^{19}$ Data on net capital stock exist at the two-digit SIC level, whereas data on all other variables are available at the three-digit SIC level. The French nomenclature differs slightly from the American; the SIC terminology is used for simplicity.

${ }^{20}$ Berman et al.(1994), as well as Feenstra and Hanson (1996, 1997), equate $Y$ to value added. However, because of the unavailability of certain price deflators, these authors use shipment in their empirical estimates. Consequently, using value added and gross output interchangeably when performing the regression analysis do not seem to be an issue of major concern.
} 
hypothesis of an insignificant $Y$ is systematically rejected at the $1 \%$ significance level. The output level controls for industry scale. Such control is especially important owing to the French labor market's inflexibility. Firms willing to alter their share of unskilled to skilled labor encounter difficulties in laying off workers because of strong unions and protective labor laws. Hence, changes in the share of unskilled labor in employment often occur as firms increase production.

The endogeneity of output is also considered as a potential issue. I therefore perform an instrumental variable estimation using the lagged value of $Y$ as the instrumental variable. (Table 7 reports results for standard and instrumental variable estimation for both the 1982-1987 and 1987-1992 periods). The coefficient for output varies across specifications, but that on international vertical specialization is not greatly affected by the change in specification.

Finally, I consider the possibility of multicollinearity. The tests for correlation between output and vertical specialization and for correlation between output and capital utilization do not show any evidence of multicollinerarity (the correlations are always under 0.7 and include some extremely low levels, depending on the considered data).

Data are weighted by the industry's average share in total manufacturing employment over each period. A weighted least-squares estimation is conducted, which considerably reduces the industry-specific heteroskedasticity. The weights have been chosen so that, over each period, summing up the dependent variables gives the total within-industry change. I estimate the slope parameters by running regression (5.2) over the 1977-1985 and 1985-1993 periods combined. Variables are in annual changes averaged over the corresponding period. ${ }^{22}$ Both OECD and nonOECD measures of international vertical specialization are considered. Robustness is checked by extending the time period to three subperiods: 1977-1982, 1982-1987, and 1987-1992. Further exploitation of the time-series properties of the data could give misleading results, since the longrun change relationship may not be isolated from business-cycle effects. ${ }^{23}$

\footnotetext{
${ }^{21}$ All the estimations were conducted using value added. Results are not reported in this paper but are available upon request.

${ }^{22}$ For example, averaged over the $1977-1985$ period for the $1977-1985$ change.

${ }^{23}$ Results are available upon request.
} 
Table 5 gives the annual rates of change in the (logarithmic) variables for the three-digit industry sample. As reported in Section 4, we observe an annual within-industry decrease in the share of unskilled workers in total employment, with a deceleration in the second period. This share decreases at a rate of 0.49 annual percentage points in the first period and of 0.44 annual percentage points in the second period. The annual growth rate of production rises over time, and production becomes more capital-intensive in both periods regardless of the measure chosen to proxy capital. However, while the growth rate of net capital stock used in production rises over the two periods (results obtained at the two-digit industry level), the electricity used in production increases at a decreasing rate. Most notably, vertical specialization increases over both periods with an acceleration over time. The growth rate of vertical specialization is 0.094 percent per year for 1977-1985 and 0.185 percent per year for 1985-1993. Finally, the table shows that the growth rate in vertical specialization involving non-OECD countries is actually slightly negative in the first period and is lower than growth in vertical specialization from OECD countries in both periods.

\section{- Insert Table 5 -}

The regression results for equation (5.2) are presented in Tables 6 and 7. In Table 6, the subperiods 1977-1985 and 1985-1993 are combined; in Table 7, the subperiods 1982-1987 and 1987-1992 are combined. Estimations are made using net capital stock at the two-digit SIC (Standard Industrial Classification) level and using electricity consumption at the three-digit SIC level. Specification (1) in Table 6 reports unweighted estimates based on the two-digit industry sample, while specification (2) reports unweighted estimation using the three-digit industry sample. Specifications (3) and (4) provide the corresponding weighted estimates. In specifications (4), (4'), and (4"), results are reported for all countries combined, OECD countries, and non-OECD countries, respectively. In Table 7, the instrumental variable estimations are presented. Specifications (5), (5'), and (5") provide estimates of the variables for all countries combined, OECD countries, and non-OECD countries using current output value for $Y$, whereas 
specifications (6), (6'), and (6") utilize lagged values of output as the instrumental variable for $\mathrm{Y}^{24}$

\section{- Insert Tables 6 \& 7 -}

In all specifications, the coefficient of international vertical specialization, which ranges between -0.408 and -0.857 , is statistically and economically significant. The decomposition by country source of imports shows similar features. Results on capital utilization are ambiguous. In most (but not all) cases, coefficients have the expected negative sign, which reflects the substitutability between unskilled labor and capital. However, the capital coefficients are all statistically insignificant and make only a small contribution in explaining the decline in the share of unskilled workers in employment. The observed deceleration in the annual rate of change in the share of unskilled workers in employment is mirrored by the positive coefficient on the time dummy. This is especially significant in specifications (5) and (6) and can be explained by the large deceleration in the annual decrease in the share of unskilled employment that occurred between the two periods: from -0.515 during $1982-1987$ to -0.415 during $1987-1992$.

Tables 6 and 7 also report the contributions of the increase in vertical specialization to the decline in the share of unskilled workers in manufacturing employment. These are calculated by multiplying the slope coefficients by the annual rate of change in the corresponding variable and dividing them by the annual rate of change in the share of unskilled workers. For example, consider specification (4)'s vertical specialization coefficient of -0.584 in Table 6 . In the first period, the annual growth rate in vertical specialization at the three-digit industry level is 0.094 . Dividing the product of these two numbers by the annual rate of change in the share of unskilled labor of -0.485 for this period (see Table 5) yields a figure of $11 \%$ for the contribution of vertical specialization to the annual decrease in the share of unskilled workers in manufacturing employment for the 1977-1985 period. The contribution of vertical specialization is always positive for all countries and for OECD countries alone and varies between 11\% and 26\% over the two periods. Moreover, contributions do not significantly vary with either the sample size or

\footnotetext{
${ }^{24}$ A likelihood ratio test and a Wald test are used to test the hypothesis of groupwise heteroscedasticity. A Breush-Pagan Lagrange multiplier test is used to test the hypothesis of cross-sectional correlation.
} 
the choice made to proxy capital utilization (see specifications (3) and (4)). In specification (4), which is the preferred specification due to its high level of disaggregation, vertical specialization contributes $11 \%$ of the annual decline in the share of unskilled workers in manufacturing employment for 1977-1985 and 25\% for 1985-1993. The observed acceleration in vertical specialization corresponds to an increase in its contribution to the decline in the share of unskilled workers. The persistently low level of non-OECD vertical specialization is reflected by a negligible contribution during 1977-1985, but this contribution reaches 10\% during 1985-1993 as non-OECD vertical specialization takes off.

The results described here are consistent with those found by Feenstra and Hanson $(1996,1997)$. These authors find that vertical specialization contributes from $11 \%$ to $15.2 \%$ of the decline in the share of production workers in the wage bill over the 1979-1990 period. They obtained these results using a limited measure of outsourcing (within the same two-digit industries) that is similar to mine. I believe that our results are in line; data discrepancy and country specificity explain the limited differences. The decrease in the share of unskilled workers in manufacturing employment that is not explained by changes in measured factors is presumably caused by skilled-biased technological change and/or some institutional factors.

\section{Conclusion}

Vertical specialization rose dramatically in France over the 1977-1993 period. To the extent that this increase is due to a decline in trade costs, one expects globalization to affect the relative wages and employment shares of skilled and unskilled workers - by shifting relative labor demand across countries. In the case of France, which is typical of Continental Europe countries, the relative wages of skilled to unskilled labor have been comparatively stable for various institutional reasons over the period examined. Consequently, globalization has manifested itself mainly in the form of a significant decline in the within industry share of unskilled workers.

Regression analysis indicates that vertical specialization has contributed appreciably to the observed decline in the within-industry share of unskilled workers in French manufacturing 
employment. It accounts for $11 \%$ to $15 \%$ of the within-industry shift away from unskilled workers toward skilled workers over the 1977-1985 period and to about 25\% over the 19851993 period. Although such figures are not negligible, most of the increase in inequality has other causes, among which skilled-biased technological progress presumably is the most important contributing element. It is striking, consequently, to observe that, whereas globalization often incites strong criticism, it is rare to hear that technological progress should be limited because of its effect on income distribution. In fact, policies should be encouraged that aim at supporting (via training or relocation subsidies) those unskilled workers who suffer from the effects of international integration. However, policies in line with the view of anti-globalization groups, which would aim at reducing trade and thereby vertical specialization, are economically inappropriate, as international trade has been widely shown to increase average welfare.

Acemoglu, D.2000, “Technical Change, Inequality and Labor Market," NBER working paper \#7800.

Anxo, D. and T. Sterner, 1994, "Using Electricity Data to Measure Capital Utilization," Energy Economics 16(1): 63--74.

Berman, E., J. Bound and Z. Griliches, 1994, "Change in the Demand for Skilled Labor within U.S. Manufacturing: Evidence from the Annual Survey of Manufactures," Quarterly Journal of Economics 109 (May): 367--98.

Bound, J. and G. Johnson, 1992, "Changes in the Structure of Wages in the 1980s: An Evaluation of Alternative Explanations," American Economic Review 82 (June): 371--92.

Brown, R. and L. Christensen, 1981, "Estimating Elasticities of Substitution in a Model of Partial Static Equilibrium: An Application to U.S. Agriculture, 1947 to 1974," in E. Berndt and B. Fiel (Eds.), Modeling and Measuring Natural Resource Substitution, pp. 209 - 29 Cambridge, MA : MIT Press.

Burnside, C., M. Eichenbaum and S. Rebelo, 1995, "Capital Utilization and Returns to Scale," NBER working paper $\# 5125$.

Campa, J. and L. Goldberg, 1997, “The Evolving External Orientation of Manufacturing: Evidence from Four Countries, NBER working paper \#5919.

Cortes, O. and S. Jean, 1997, Quel est l'impact du commerce extérieur sur la productivité et l'emploi?" CEPII working paper \#97-08. 
Costello, D., 1993, “A Cross-Country Comparison of Productivity Growth," Journal of Political Economy 101 (April): 207--22.

Feenstra, R., 1998, "Integration of Trade and Disintegration of Production in the Global Economy," Journal of Economic Perspectives 12(4) : 31--51.

Feenstra, R. and G. Hanson,1996, "Foreign Investment, Outsourcing and Relative Wages," in R. C. Feenstra, G. M. Grossman, and D. Irwin (Eds.), The Political Economy of Trade Policy: Essays in Honor of Jagdish Bhagwati., pp. 89--127, Cambridge, MA: MIT Press.

Feenstra, R. and G. Hanson, 1997 "Foreign Direct Investment and Relative Wages: Evidence from Mexico's Maquiladoras," Journal of International Economics 42 (May): 371--94.

Griliches, Z. and D. Jorgenson, 1967, "'The Explanation of Productivity Change," Review of Economic Studies 34: 249--80.

Hummels, D., D. Rapoport and K.,Yi, 1998, "Vertical Specialization and the Changing Nature of World Trade," Federal Reserve Bank of New York Economic Policy Review (June) : 79--99.

Hummels, D., J.,Ishii and K.,Yi, 1999, "The Nature and Growth of Vertical Specialization in World Trade, "Federal Reserve Bank of New York working paper (August).

Krugman, P., 1995, "Growing World Trade: Causes and Consequences," Brookings Papers on Economic Activity 1: 327--77.

Lawrence, R. and M., Slaughter, 1993, "International Trade and American Wages in the 1980s: Giant Sucking Sound or Small Hiccup?" Brookings Papers on Economic Activity Microeconomics, 2: 161--226.

Machin, S., A. Ryan and J.,Van Reenan, 1996, "Technology and Changes in Skill Structure: Evidence from an International Panel of Industries," Center for Economic Performance discussion paper \#297.

OECD (Organization for Economic Cooperation and Development), 1996 \& 1997, Employment Outlook.

Strauss-Kahn, V., 2002, "Firms' Location Decision Across Asymmetric Countries and Employment Inequality," INSEAD working paper.

Thesmar, D. and M. Thoenig, 2002, "Outsourcing, Product Market Entry and the Rise in Job Uncertainty," Paper presented at the European Research Workshop in International Trade, CEPR, Munich, June 2002. 
Table 1. Index $V$ and Limited Index $V l$ of International Vertical Specialization: Overall and Selected Results

\begin{tabular}{|c|c|c|c|}
\hline $\boldsymbol{V}$ & 1977 & 1993 & $\%$ Growth \\
\hline Overall & 0.092 & 0.138 & 50.0 \\
\hline Apparel and Other Fabricated Textile Products & 0.080 & 0.181 & 126.3 \\
\hline Synthetic Fibers & 0.164 & 0.323 & 96.9 \\
\hline Miscellaneous Plastic Products & 0.155 & 0.303 & 95.5 \\
\hline Textile Industries & 0.097 & 0.188 & 93.8 \\
\hline Aircraft & 0.129 & 0.239 & 85.3 \\
\hline Motor Vehicles & 0.084 & 0.154 & 83.3 \\
\hline Non-Electrical Industrial Machinery & 0.093 & 0.169 & 81.7 \\
\hline Industrial Chemicals & 0.117 & 0.196 & 67.5 \\
\hline Farm Machinery and Equipment & 0.083 & 0.137 & 65.1 \\
\hline Electronic Computing Equipment & 0.081 & 0.123 & 51.9 \\
\hline Primary Steel Industries & 0.143 & 0.216 & 51.0 \\
\hline Metalworking Machinery & 0.067 & 0.098 & 46.3 \\
\hline Wood Product & 0.093 & 0.074 & -20.4 \\
\hline Iron Mining & 0.085 & 0.030 & -64.7 \\
\hline$V l$ & 1977 & 1993 & \% Growth \\
\hline Overall & 0.049 & 0.073 & 49.0 \\
\hline Miscellaneous Plastic Products & 0.012 & 0.037 & 208.3 \\
\hline Apparel and Other Fabricated Textile Products & 0.072 & 0.164 & 127.8 \\
\hline Textile Industries & 0.059 & 0.127 & 115.3 \\
\hline Synthetic Fibers & 0.136 & 0.279 & 105.2 \\
\hline Motor Vehicles & 0.039 & 0.079 & 102.6 \\
\hline Aircraft & 0.107 & 0.212 & 98.1 \\
\hline Industrial Chemicals & 0.085 & 0.168 & 97.7 \\
\hline Electronic Computing Equipment & 0.042 & 0.079 & 88.1 \\
\hline Farm Machinery and Equipment & 0.028 & 0.047 & 67.9 \\
\hline Non-Electrical Industrial Machinery & 0.049 & 0.080 & 63.3 \\
\hline Metalworking Machinery & 0.015 & 0.024 & 60.0 \\
\hline Primary Steel Industries & 0.139 & 0.208 & 49.6 \\
\hline Wood Product & 0.084 & 0.059 & -29.8 \\
\hline Iron Mining & 0.016 & 0.004 & -75.0 \\
\hline
\end{tabular}


Table 2. Industry/Sector Decomposition of the Rise in International Vertical Specialization ${ }^{25}$

\begin{tabular}{|c|c|c|c|c|}
\hline $\boldsymbol{V}$ & Between & Within & Total & Within/Total \\
\hline 1977-1985 & 0.00 & 0.20 & 0.20 & $101 \%$ \\
\hline 1985-1993 & 0.01 & 0.30 & 0.31 & $97 \%$ \\
\hline 1977-1993 & 0.01 & 0.27 & 0.27 & $98 \%$ \\
\hline$V l$ & Between & Within & Total & Within/Total \\
\hline 1977-1985 & 0.00 & 0.09 & 0.10 & $98 \%$ \\
\hline 1985-1993 & -0.01 & 0.18 & 0.17 & $105 \%$ \\
\hline 1977-1993 & 0.00 & 0.14 & 0.14 & $101 \%$ \\
\hline
\end{tabular}

Sources: INSEE; author calculation.

Table 3: Source Decomposition of the Rise in International Vertical Specialization: Domestic versus Foreign ${ }^{24}$

\begin{tabular}{ccccc}
\hline $\boldsymbol{V}$ & Between & Within & Total & Between/Total \\
\hline $\mathbf{1 9 7 7 - 1 9 8 5}$ & 0.23 & -0.02 & 0.21 & $112 \%$ \\
$\mathbf{1 9 8 5}-\mathbf{1 9 9 3}$ & 0.31 & -0.01 & 0.30 & $103 \%$ \\
$\mathbf{1 9 7 7 - 1 9 9 3}$ & 0.30 & -0.02 & 0.27 & $108 \%$ \\
\hline $\boldsymbol{r} \boldsymbol{l}$ & Between & Within & $\underline{\text { Total }}$ & Between/Total \\
\hline $\mathbf{1 9 7 7 - 1 9 8 5}$ & 0.11 & -0.01 & 0.09 & $114 \%$ \\
$\mathbf{1 9 8 5}-\mathbf{1 9 9 3}$ & 0.19 & -0.01 & 0.18 & $103 \%$ \\
$\mathbf{1 9 7 7 - 1 9 9 3}$ & 0.16 & -0.01 & 0.14 & $108 \%$ \\
\hline
\end{tabular}

Sources: INSEE; author calculation.

\footnotetext{
${ }^{25}$ The columns "Total" reports the sum of the within and the between components. Due to rounding, "Total" numbers vary slightly across tables.
} 
Table 4A. Industry/Sector Decomposition of the Decline in the Share of Unskilled Workers: All Sectors

\begin{tabular}{lcccc}
\hline & Between & Within & Total & Within/Total \\
\hline $\mathbf{1 9 7 7 - 1 9 8 5}$ & -0.24 & -0.40 & -0.65 & $63 \%$ \\
$\mathbf{1 9 8 5}-\mathbf{1 9 9 3}$ & -0.21 & -0.48 & -0.69 & $70 \%$ \\
$\mathbf{1 9 7 7 - 1 9 9 3}$ & -0.23 & -0.44 & -0.67 & $65 \%$ \\
\hline \multicolumn{2}{l}{ Sources: INSEE; author calculations. }
\end{tabular}

Sources: INSEE; author calculations.

Table 4B. Industry/Sector Decomposition of the Decline in the Share of Unskilled Workers: Manufacturing Sectors

\begin{tabular}{ccccc}
\hline & Between & Within & Total & Within/Total \\
\hline $\mathbf{1 9 7 7 - 1 9 8 5}$ & -0.08 & -0.49 & -0.57 & $86 \%$ \\
$\mathbf{1 9 8 5}-\mathbf{1 9 9 3}$ & -0.06 & -0.43 & -0.50 & $88 \%$ \\
$\mathbf{1 9 7 7 - 1 9 9 3}$ & -0.08 & -0.46 & -0.53 & $86 \%$ \\
\hline
\end{tabular}

Sources: INSEE; author calculations. 
Table 5. Mean Rate of Change of Variables

\begin{tabular}{|l|c|c|}
\hline & $\mathbf{1 9 7 7 - 1 9 8 5}$ & $\mathbf{1 9 8 5}-\mathbf{1 9 9 3}$ \\
\hline $\boldsymbol{\delta} \boldsymbol{E}_{\boldsymbol{u}}$ & & \\
\hline$\delta \ln ($ Kelc $/ \boldsymbol{Y})$ & -0.485 & -0.435 \\
\hline $\boldsymbol{\delta} \ln (\boldsymbol{Y})$ & 2.345 & 1.905 \\
\hline $\boldsymbol{\delta}$ & 0.954 & 1.060 \\
\hline $\boldsymbol{\delta}$ Voecd & 0.094 & 0.185 \\
\hline $\boldsymbol{\delta}$ Vnoecd & 0.102 & 0.146 \\
\hline
\end{tabular}

Sources: Author calculations; Cortes and Jean (1997) database for labor data; INSEE for data on output capital, and vertical specialization.

Notes: Data are weighted by the industry share of unskilled employment in

Total manufacturing employment. The sample consists of 50 three-digit industries. Variables are defined as:

$\delta E u=100 *$ annual change in unskilled workers' share of total employment,

$\delta \ln (\operatorname{Kelc} / Y)=100 *$ annual change in $\ln [($ electricity consumption $) /($ real output $)]$,

$\delta \ln (Y)=100 *$ annual change in $\ln ($ real output $)$

$\delta V=100 *$ annual change in vertical specialization. 
Table 6. Regression Results: 1977-1993

\begin{tabular}{|c|c|c|c|c|c|c|}
\hline Specification & (1) & $(2)$ & (3) & (4) & (4') & $\left(4^{\prime \prime}\right)$ \\
\hline$\delta \ln (K / Y)$ & $\begin{array}{c}0.008 \\
(0.034)\end{array}$ & $\begin{array}{l}-0.014 \\
(0.015)\end{array}$ & $\begin{array}{l}-0.028 \\
(0.030)\end{array}$ & $\begin{array}{c}0.002 \\
(0.015)\end{array}$ & $\begin{array}{c}0.001 \\
(0.016)\end{array}$ & $\begin{array}{c}0.004 \\
(0.015)\end{array}$ \\
\hline$\delta \ln (Y)$ & $\begin{array}{c}-0.063 * * * \\
(0.025)\end{array}$ & $\begin{array}{c}-0.032 * * * \\
(0.012)\end{array}$ & $\begin{array}{c}-0.126^{* * * *} \\
(0.029)\end{array}$ & $\begin{array}{c}-0.082^{* * *} \\
(0.02)\end{array}$ & $\begin{array}{c}-0.079 * * * \\
(0.02)\end{array}$ & $\begin{array}{c}-0.081 * * * \\
(0.021) \\
\end{array}$ \\
\hline$\delta V$ & $\begin{array}{c}-0.511^{* *} \\
(0.282)\end{array}$ & $\begin{array}{c}-0.703 * * * \\
(0.225)\end{array}$ & $\begin{array}{c}-0.857 * * * \\
(0.331)\end{array}$ & $\begin{array}{c}-0.584 * * * \\
(0.180)\end{array}$ & & \\
\hline$\delta$ Voecd & & & & & $\begin{array}{c}-0.690 * * * \\
(0.196)\end{array}$ & \\
\hline$\delta$ Vnoecd & & & & & & $\begin{array}{c}-1.175^{* *} \\
(0.552) \\
\end{array}$ \\
\hline Constant & $\begin{array}{c}-0.348 * * * \\
(0.073)\end{array}$ & $\begin{array}{c}-0.301 * * * \\
(0.067)\end{array}$ & $\begin{array}{c}-0.291 * * * \\
(0.064)\end{array}$ & $\begin{array}{c}-0.357 * * * \\
(0.065)\end{array}$ & $\begin{array}{c}-0.342 * * * \\
(0.065)\end{array}$ & $\begin{array}{c}-0.428 * * * \\
(0.054)\end{array}$ \\
\hline $1985-1993$ & $\begin{array}{l}-0.052 \\
(0.095)\end{array}$ & $\begin{array}{l}-0.093 \\
(0.084) \\
\end{array}$ & $\begin{array}{l}0.138^{*} \\
(0.090)\end{array}$ & $\begin{array}{l}0.114 \\
0.091 \\
\end{array}$ & $\begin{array}{l}0.091 \\
0.093 \\
\end{array}$ & $\begin{array}{l}0.126^{*} \\
0.093\end{array}$ \\
\hline Adj. $R$-squared & 0.123 & 0.091 & 0.453 & 0.438 & 0.423 & 0.415 \\
\hline $\begin{array}{c}\text { Contribution } V \\
1977-1985 \\
\end{array}$ & & & $15 \%$ & $11 \%$ & $15 \%$ & $0 \%$ \\
\hline $\begin{array}{c}\text { Contribution } V \\
1985-1993 \\
\end{array}$ & & & $26 \%$ & $25 \%$ & $23 \%$ & $10 \%$ \\
\hline \# of observations & 44 & 100 & 44 & 100 & 100 & 100 \\
\hline
\end{tabular}

Sources: Author calculations; Cortes and Jean (1997) database for labor data; INSEE for data on output capital, and vertical specialization.

Notes: The dependent variable is annul change in ratio of unskilled employment to total employment. Regressions weighted by the average share of industry employment in total manufacturing employment.

Numbers in parentheses are the estimated white standard errors, which are robust to cross-section heteroskedasticity and correlation. Coefficient with a $* * * * *, *$ are significant at a $1 \%, 5 \%$, and $10 \%$ level. 
Table 7. Regression Results: 1982-1992

\begin{tabular}{|c|c|c|c|c|c|c|}
\hline Specification & (5) & $\left(5^{\prime}\right)$ & $(5, ')$ & (6) & $\left(6^{\prime}\right)$ & $\left(6^{\prime \prime}\right)$ \\
\hline$\delta \ln (K / Y)$ & $\begin{array}{l}-0.010 \\
(0.016)\end{array}$ & $\begin{array}{l}-0.011 \\
(0.016)\end{array}$ & $\begin{array}{l}-0.006 \\
(0.016)\end{array}$ & $\begin{array}{l}-0.027 \\
(0.022)\end{array}$ & $\begin{array}{l}-0.028 \\
(0.023)\end{array}$ & $\begin{array}{l}-0.017 \\
(0.022)\end{array}$ \\
\hline$\delta \ln (Y)$ & $\begin{array}{l}-0.069 * * * \\
(0.019)\end{array}$ & $\begin{array}{l}-0.067 * * * \\
(0.020)\end{array}$ & $\begin{array}{l}-0.070 * * * \\
(0.019)\end{array}$ & $\begin{array}{l}-0.147 * * * \\
(0.0391)\end{array}$ & $\begin{array}{l}-0.145^{* * *} \\
(0.039)\end{array}$ & $\begin{array}{l}-0.135 * * * \\
(0.040)\end{array}$ \\
\hline$\delta V$ & $\begin{array}{l}-0.408 * * * \\
(0.144)\end{array}$ & & & $\begin{array}{l}-0.465 * * * \\
(0.157)\end{array}$ & & \\
\hline$\delta$ Voecd & & $\begin{array}{l}-0.513^{* * *} \\
(0.206)\end{array}$ & & & $\begin{array}{l}-0.481 * * * \\
(0.190)\end{array}$ & \\
\hline$\delta$ Vnoecd & & & $\begin{array}{l}-1.178^{* * *} \\
(0.399)\end{array}$ & & & $\begin{array}{l}-1.219^{* * *} \\
(0.491)\end{array}$ \\
\hline Constant & $\begin{array}{l}-0.378 * * * \\
(0.079)\end{array}$ & $\begin{array}{l}-0.382 * * * \\
(0.080)\end{array}$ & $\begin{array}{l}-0.401 * * * \\
(0.076)\end{array}$ & $\begin{array}{l}-0.271 * * * \\
(0.109)\end{array}$ & $\begin{array}{l}-0.274 * * * \\
(0.107)\end{array}$ & $\begin{array}{l}-0.362 * * * \\
(0.110)\end{array}$ \\
\hline 1987-1992 & $\begin{array}{l}0.209^{* * * *} \\
(0.081)\end{array}$ & $\begin{array}{l}0.199 * * * \\
(0.081)\end{array}$ & $\begin{array}{l}0.222 * * * \\
(0.081)\end{array}$ & $\begin{array}{l}0.307 * * * \\
(0.102)\end{array}$ & $\begin{array}{l}0.294 * * * \\
(0.103)\end{array}$ & $\begin{array}{l}0.303 * * * \\
(0.098)\end{array}$ \\
\hline Adj. $R$-squared & 0.313 & 0.310 & 0.317 & 0.196 & 0.183 & 0.207 \\
\hline $\begin{array}{c}\text { Contribution } V \\
1982-1987\end{array}$ & $13 \%$ & $12 \%$ & $10 \%$ & $15 \%$ & $14 \%$ & $0 \%$ \\
\hline $\begin{array}{c}\text { Contribution } V \\
1987-1992 \\
\end{array}$ & $20 \%$ & $18 \%$ & $18 \%$ & $23 \%$ & $20 \%$ & $10 \%$ \\
\hline$\#$ of observations & 100 & 100 & 100 & 100 & 100 & 100 \\
\hline
\end{tabular}

Sources: Author calculations; Cortes and Jean (1997) database for labor data; INSEE for data on output capital, and vertical specialization.

Notes: The dependent variable is annul change in ratio of unskilled employment to total employment. Regressions weighted by the average share of industry employment in total manufacturing employment.

Numbers in parentheses are the estimated white standard errors, which are robust to cross-section heteroskedasticity and correlation. Coefficient with a $* * * * *, *$ are significant at a $1 \%, 5 \%$, and $10 \%$ level. 
